\title{
Disease burden affecting pig production in Nigeria: Review of current issues and challenges
}

\author{
Ikechukwu O. Igbokwe ${ }^{1 *}$ Chima V. Maduka ${ }^{1,2}$
}

\section{Keywords}

Swine, animal production, virosis, bacterial disease, parasitosis, gastrointestinal disease, morbidity, Nigeria

Submitted: 19 July 2017

Accepted: 11 April 2018

Published: 9 July 2018

DOI : $10.19182 /$ remvt.31290

\begin{abstract}
Summary
The increased interest in pig production as a complementary source of animal protein has led to pig population growth in Nigeria. Disease outbreaks represent the major constraint to profitable pig production in locations where there is absence of religious barriers to pork production and consumption. Important pig diseases reported in the country and the location of the pig population affected are highlighted in this review. African swine fever, foot-and-mouth disease, brucellosis, trypanosomosis, babesiosis, eperythrozoonosis, helminthosis, coccidiosis and other parasitoses impact on the production system by negatively affecting feed conversion efficiency, reproduction and growth rates as well as causing piglet and adult mortalities. The economic losses due to the disease burden and inadequate intervention strategies are current issues facing the pig production industry. The risk of zoonotic spread of influenza, trypanosomiasis, larva migrans, teniasis, mange, cryptosporidiosis, balantidiasis, ancylostomiasis, entamoebiasis and jigger fleas from affected pigs is real. Disease control strategies through the provision of veterinary resources and services need attention, and a paradigm shift is required for sustainability and expansion of the pig production capacity in the country.
\end{abstract}

- How to quote this article: Igbokwe I.O., Maduka C.V., 2018. Disease burden affecting pig production in Nigeria: Review of current issues and challenges. Rev. Elev. Med. Vet. Pays Trop., 71 (1-2): 87-95, doi: 10.19182/remvt.31290

\section{INTRODUCTION}

Nigeria is one of the African countries with significant pig population density (Robinson et al., 2014). In the 1990s, the pig population was 3.5 million consisting of native black hairy pigs and exotic breeds. A map of its spatial distribution at that time is presented in Figure 1 (Bourn et al., 1994). The latest population estimate was reported by the National Agricultural Sample Survey in 2011 to have increased to 7.1 million (unfortunately without an updated spatial map), indicating that the population had doubled in about two decades. The pigs are reared in neighborhoods of villages and in semiurban areas as small-scale enterprises having 1-50 pigs, but a few large-scale farms exist (Ajala et al., 2006; Saka et al., 2010; Abiola et al., 2015). Semi-intensive and

\footnotetext{
1. Strategic Animal Research Group, Faculty of Veterinary Medicine, University of Maiduguri, PO Box 8000 (Private), Maiduguri, Nigeria.

2. Comparative Medicine and Integrative Biology, College of Veterinary Medicine, Michigan State University, East Lansing, USA.

* Corresponding author

Email: ikeigbokwe@gmail.com; ikeigbokwe@unimaid.edu.ng

extensive pig production systems occur in the Northern, Middle Belt and Niger Delta regions of Nigeria (Bourn et al., 1994). Intensive pig rearing exists mostly in Southern Nigeria (Ajala et al., 2006; Saka et al., 2010; Nwanta et al., 2011) and consists of farms having each 50-200 pigs in concrete pens. Commercial piggeries rear about $3 \%$ of the national pig population with usually more than five breeding sows per farm (Bourn et al., 1994). More men than women are involved in these enterprises in Southern Nigeria, whereas the opposite is the case in Northern Nigeria (Bawa et al., 2004; Ajala et al., 2006; Machebe et al., 2009; Nwanta et al., 2011; Abiola et al., 2015). In Southern Nigeria and some parts of Northern Nigeria, the majority of these farmers are educated and they combine pig farming with other business activities (Machebe et al., 2009; Nwanta et al., 2011; Abiola et al., 2015). Pig farming has been reported to yield good income despite the constraints associated with its production systems in various locations of the country (Ajala and Adesehinwa, 2008). Pigs play a vital role in the culture and tradition of people in some parts of Nigeria where they are used for celebrations and festivities such as marriages, burial rites and naming ceremonies (Fasina et al., 2010).

Sustainable growth of the pig production industry in Nigeria is adversely affected by factors such as unstructured pig marketing framework, fluctuations in the prices of pigs and pig products, cultural 


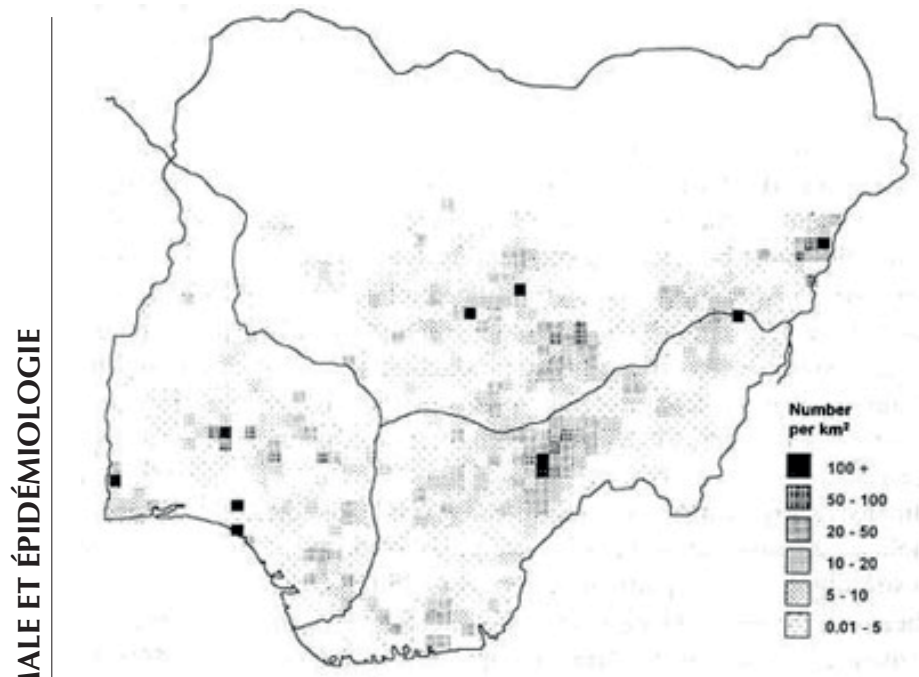

Figure 1: Pig distribution in Nigeria; estimated population of 3.5 million in the 1990s (Bourn et al., 1994).

and religious prohibition of pork consumption, low demand for pork in parts of the country, high feed cost, inadequate extension services, slow integration of cost-effective equipment and genetically enhanced breeds, and disease outbreaks (Ajala and Adesehinwa, 2008; Ironkwe and Amefule, 2008; Fasina et al., 2010; Saka et al., 2010; Anukwu and Ebong, 2011; Abiola et al., 2015). The disease burden limits significant profitable pig farming in Nigeria. Adequate knowledge of prevalent diseases affecting pigs in the country is a prerequisite for the proper planning of effective preventive and control measures to reduce their associated cost burden on the production system and boost the profit margin. Therefore, in this review we have examined all the published researches using the PubMed site and Google search engine, or retrieving it from local institutional libraries and through contacts of authors, to gather information aimed at highlighting diseases that have been reported in pigs reared in Nigeria, with a focus on the current disease-related issues challenging profitable pig production.

\section{AFRICAN SWINE FEVER}

African swine fever (ASF) is a viral disease of pigs caused by an Asfivirus in the family Asfarviridae which is highly contagious and often fatal (Ayoade and Adeyemi, 2003). The first isolate of the virus from pigs in Nigeria has been characterized by Odemuyiwa et al. in 2000. The acute disease in pigs causes multifocal skin hemorrhages on the ventral abdomen, interstitial pneumonia, acute orchitis and meningitis, lymphoid necrosis, and focal hemorrhages in nervous tissues (Otesile et al., 2005). Outbreaks of the disease in the country occurred in 1997, 1998, 2001, and the subclinical disease has persisted as an enzootic condition (Otesile et al., 2005; Babalobi et al., 2007; Awosanya et al., 2015). Over 500,000 pigs died from ASF in Nigeria within the first few years of the confirmed outbreaks (Majiyagbe et al., 2004). The confirmed outbreaks of ASF in Nigeria (Figure 2) affected Plateau, Nasarawa, Benue, Oyo, Kaduna, Bauchi, Taraba, Adamawa, Lagos, Enugu, Ogun, Akwa Ibom, Cross Rivers, Rivers, Gombe, Osun, Ondo, Ekiti, Anambra, Edo, and Delta States (Majiyagbe et al., 2004; Babalobi et al., 2007; Mailafia and Iliya, 2009; Fasina et al., 2010; Owolodun et al., 2010a, 2010b; Abwage et al., 2015; Adenaike et al., 2016; Awosanya et al., 2015; Ayas et al., 2016). Therefore, pigs in 21 (56.8\%) out of 36 states and the Federal Capital Territory (FCT) were involved in outbreaks. Most of the Northern States did not report any, probably because of the negligible pig population or a lack of surveillance network in those locations (Table I). The average loss per farm incurred from ASF outbreak was over 3000 US\$ (Babalobi et al., 2007). The epidemiological cycle of ASF in Nigeria is maintained by domestic pigs without confirmed participation of other hosts or vectors (Fasina et al., 2010). Although ASF virus is virulent, resulting in high morbidity and mortality (Majiyagbe et al., 2004; Babalobi et al., 2007; Fadiga et al., 2013), recent findings point to the emergence of a mild strain of the virus which causes persistent infection, thereby maintaining the endemicity of ASF in Nigeria (Fasina et al., 2010; Owolodun et al., 2010a). This may account for the steady increase in the seroprevalence of ASF in Nigeria (Fadiga et al., 2013), especially in Northern agroecological areas (Adamawa, Taraba, Gombe, Bauchi), where it had been hitherto absent. The persistence of the virus and spread of infection in the country is through unchecked movement of infected pigs, outbreak survivors and infected pig products because of inadequate surveillance (Babalobi et al., 2007; Olugasa and Ijagbone, 2007; Fasina et al., 2010).

\section{FOOT-AND-MOUTH DISEASE}

Foot-and-mouth disease (FMD) is a viral disease caused by an Aphthovirus in the family Picornaviridae. It is a contagious vesicular disease of cloven-footed livestock which has been reported to be endemic in Nigeria (Ularamu et al., 2016), but outbreaks used to be sporadic and associated with imported trade cattle from neighboring countries (Nawathe and Goni, 1976). Seropositivity for FMD virus was reported in Plateau, Enugu, Taraba, Adamawa, Kebbi and Oyo States with seroprevalence rates ranging from $2 \%$ to $46 \%$ (Fakai et al., 2015; Aiki-Raji et al., 2016). Clinical FMD in pigs causes fever, anorexia and salivation, vesicles, erosions and ulcers on the snout, tongue, hard and soft palates, skin of the interdigital space, coronary bands of the feet, and mortality of piglets (Kitching and Alexandersen, 2002; Alexandersen and Mowat, 2005).

\section{BRUCELLOSIS}

Brucellosis is a contagious bacterial disease affecting pigs caused by Brucella abortus, B. melitensis and B. suis. The disease is associated with reproductive disorders which lead to male and female infertility and abortions. Sows in Edo State were reported to have abortions and $39 \%$ of the 55 samples collected from 25 farms yielded isolates of Brucella suis predominantly, as well as of B. melitensis and $B$.

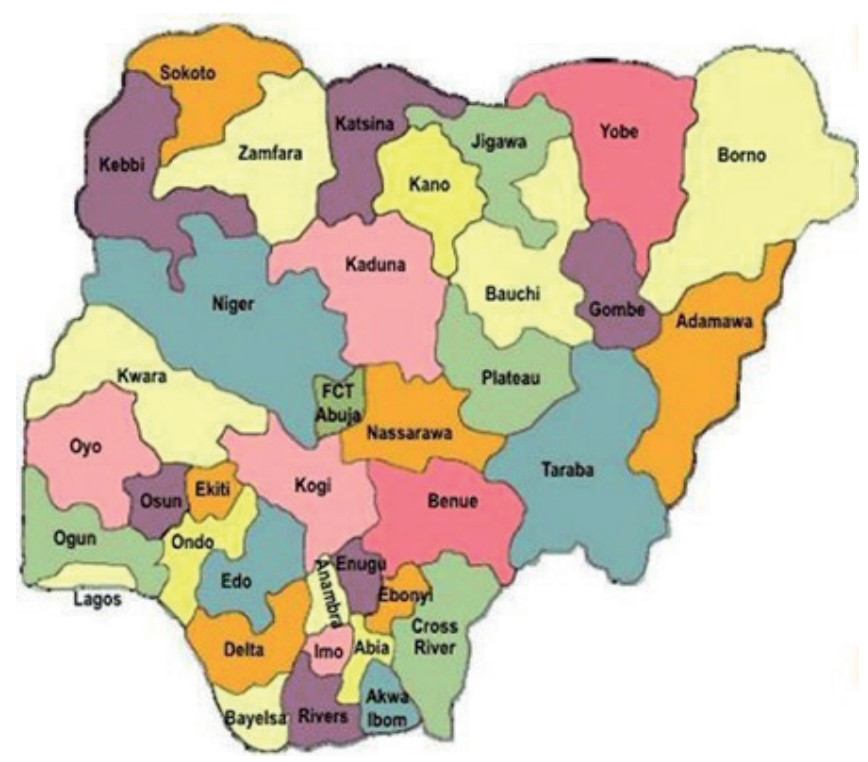

Figure 2: States of Nigeria; http://dailymail.com.ng/wp-content/ uploads/2015/01/10360606_10203337420937904_719059988 20449261_n.jpg; accessed 16 July 2017. 
Table I

Pig diseases reported in the thirty-six States and the Federal Capital Territory (FCT) of Nigeria

\begin{tabular}{|c|c|c|c|c|c|c|}
\hline \multirow[t]{2}{*}{ States } & \multicolumn{5}{|c|}{ Diseases } & \multirow[t]{2}{*}{ References } \\
\hline & ASF & FMD & BRU & END & ECT & \\
\hline Abia & -- & -- & -- & -- & -- & \\
\hline Adamawa & ++ & ++ & -- & ++ & ++ & Fasina et al., 2010; Owolodun et al., 2010b; Karshima et al., 2016 \\
\hline Anambra & ++ & -- & ++ & ++ & ++ & $\begin{array}{l}\text { Onah, 1991; Majiyagbe et al., 2004; Nwanta et al., 2011; } \\
\text { Onunkwo et al., } 2011\end{array}$ \\
\hline Akwa Ibom & ++ & -- & -- & -- & -- & Majiyagbe et al., 2004; Babalobi et al., 2007; Owolodun et al., 2010b \\
\hline Bauchi & ++ & -- & -- & -- & -- & Owolodun et al., 2010b \\
\hline Bayelsa & -- & -- & -- & -- & -- & \\
\hline Benue & ++ & -- & ++ & ++ & -- & $\begin{array}{l}\text { Omotainse et al., 2000; Majiyagbe et al., 2004; Babalobi et al., 2007; } \\
\text { Fasina et al., 2010; Owolodun et al., 2010b; Ngbede et al., } 2013\end{array}$ \\
\hline Borno & -- & -- & -- & -- & -- & \\
\hline Cross River & ++ & -- & -- & -- & -- & Fasina et al., 2010; Owolodun et al., 2010b \\
\hline Delta & ++ & -- & -- & -- & -- & $\begin{array}{l}\text { Majiyagbe et al., 2004; Babalobi et al., 2007; Fasina et al., 2010; } \\
\text { Owolodun et al., 2010b }\end{array}$ \\
\hline Ebonyi & -- & -- & ++ & ++ & ++ & Nwanta et al., 2011; Onunkwo et al., 2011 \\
\hline Enugu & ++ & ++ & ++ & ++ & ++ & $\begin{array}{l}\text { Onah and Chiejina, 1995; Onah and Ebenebe, 2003; } \\
\text { Majiyagbe et al., 2004; } \\
\text { Babalobi et al., 2007; Owolodun et al., 2010b; Anene et al., 2011; } \\
\text { Nwanta et al., 2011; Onunkwo et al., } 2011\end{array}$ \\
\hline Edo & ++ & -- & ++ & -- & -- & Owolodun et al., 2010b; Bello-Onaghise et al., 2012 \\
\hline Ekiti & ++ & -- & -- & -- & -- & Majiyagbe et al., 2004; Awosanya et al., 2015 \\
\hline Gombe & ++ & -- & -- & -- & -- & Mailafia and Iliya, 2009; Owolodun et al., 2010b \\
\hline Imo & -- & -- & -- & -- & -- & \\
\hline Jigawa & -- & -- & -- & -- & -- & \\
\hline Kaduna & ++ & -- & -- & ++ & ++ & $\begin{array}{l}\text { Majiyagbe et al., 2004; Babalobi et al., 2007; Fasina et al., 2010; } \\
\text { Owolodun et al., 2010b; Adenaike et al., } 2016\end{array}$ \\
\hline Kano & -- & -- & -- & -- & -- & \\
\hline Katsina & -- & -- & -- & -- & -- & \\
\hline Kebbi & -- & -- & -- & ++ & -- & Gweba et al., 2010 \\
\hline Kogi & -- & -- & -- & -- & -- & \\
\hline Kwara & -- & -- & -- & ++ & ++ & Ocholi et al., 1988; Oladele, 2002 \\
\hline Lagos & ++ & -- & -- & -- & ++ & $\begin{array}{l}\text { Majiyagbe et al., 2004; Babalobi et al., 2007; Ugbomoiko et al., 2008; } \\
\text { Fasina et al., 2010; Owolodun et al., 2010b; Awosanya et al., } 2015\end{array}$ \\
\hline Nassarawa & ++ & -- & -- & ++ & -- & Ayas et al., 2016 \\
\hline Niger & -- & -- & -- & -- & -- & \\
\hline Ogun & ++ & -- & -- & -- & -- & $\begin{array}{l}\text { Majiyagbe et al., 2004; Babalobi et al., 2007; Fasina et al., 2010; } \\
\text { Owolodun et al., 2010b; Awosanya et al., } 2015\end{array}$ \\
\hline Ondo & ++ & -- & -- & -- & -- & Majiyagbe et al., 2004; Awosanya et al., 2015 \\
\hline Osun & ++ & -- & -- & -- & -- & Majiyagbe et al., 2004; Awosanya et al., 2015 \\
\hline Oyo & ++ & ++ & ++ & ++ & -- & $\begin{array}{l}\text { Fasina et al., 2010; Owolodun et al., 2010b; Ademola and Onyiche, 2013; } \\
\text { Awosanya et al., 2015; Aiki-Raji et al., } 2016\end{array}$ \\
\hline Plateau & ++ & ++ & -- & ++ & -- & $\begin{array}{l}\text { Fabiyi, 1979; Salifu et al., 1990; Majiyagbe et al., 2004; } \\
\text { Babalobi et al., 2007; Fasina et al., 2010; Owolodun et al., 2010a; } \\
\text { Owolodun et al., 2010b; Gagman et al., } 2015\end{array}$ \\
\hline Rivers & ++ & -- & -- & ++ & ++ & $\begin{array}{l}\text { Salifu et al., 1990; Majiyagbe et al., 2004; Babalobi et al., 2007; } \\
\text { Ironkwe and Amefule, 2008; Owolodun et al., 2010b }\end{array}$ \\
\hline Sokoto & -- & -- & -- & -- & -- & \\
\hline Taraba & ++ & ++ & -- & ++ & -- & Owolodun et al., 2010b; Abwage et al., 2015; Karshima et al., 2016 \\
\hline Yobe & -- & -- & -- & -- & -- & \\
\hline Zamfara & -- & -- & -- & -- & -- & \\
\hline FCT & -- & -- & -- & -- & -- & \\
\hline
\end{tabular}

Diseases reported (++) or not reported (--)

ASF: African swine fever; FMD: foot-and-mouth disease; BRU: brucellosis; END: endoparasitism, consisting of hemoparasites and gastrointestinal parasites; ECT: ectoparasitism 
abortus (Bello-Onaghise et al., 2012). Previously, B. suis was isolated from piggeries located in Northern Nigeria (Bale and Nuru, 1985). In Oyo State (Ibadan), none of the pigs tested serologically were positive for brucellosis (Cadmus et al., 2006). In Enugu State, the seroprevalence for brucellosis was $0.6 \%$ (Onunkwo et al., 2011; Nwanta et al., 2011). In North-Central Nigeria, $31 \%$ of 281 pigs were seropositive (Ngbede et al., 2013), but it was contended that the high seroprevalence of brucellosis should be interpreted with caution as porcine serum could produce some false positive results in serological tests (Ducrotoy et al., 2014). The seroprevalence rate for human brucellosis reported in Ibadan, Oyo State (Cadmus et al., 2006), Jos, Plateau State (Gusi et al., 2010), Abuja, and FCT (Aworh et al., 2013), among butchers in abattoirs, was 4\%-63\%, making brucellosis an important but neglected zoonosis in Nigeria (Ducrotoy et al., 2014).

\section{- TRYPANOSOMOSIS/TRYPANOSOMIASIS}

Porcine trypanosomosis is a parasitic (protozoan) disease caused by Trypanosoma simiae, T. brucei and T. congolense. A T. simiae infection is more severe than a T. brucei or a T. congolense infection (Ilemobade and Balogun, 1981). In Nigeria, infection of pigs with T. simiae produces an acute fatal hemorrhagic disease (Isoun, 1968) due to high virulence (Onah, 1991). Trypanosoma brucei is more pathogenic than T. congolense (Omeke and Ugwu, 1991). However, Agu and Bajeh (1986) reported that the case fatality of T. brucei infection in pigs was similar to that of $T$. simiae infection. Trypanosoma simiae-infected pigs have clinical signs of fever, lethargy, paralysis of hind legs, abortion, bleeding from the nose, mouth, anus and vulva; mortality reaches $66 \%$ (Ocholi et al., 1988). Pig trypanosomosis caused by T. brucei is characterized by high parasitemia, fever, hyperemia of the skin, anemia, weakness, anorexia, recumbency, anestrus, abortion in the second trimester, weight loss, ataxia, mucopurulent ocular discharge, neutropenia, lymphocytosis and mortality, increases in serum aspartate aminotransferase, alanine aminotransferase, urea and total bilirubin (Onah, 1991; Otesile et al., 1991b; Allam et al., 2011; Anene et al., 2011). Fatal cases of T. brucei infection cause circling and wobbling of the hind legs, and severe meningoencephalitis (Otesile et al.; 1991a).

Pig death and live pig weight losses caused by trypanosomosis have cost implications in pig production in Nigeria (Fadiga et al., 2013). There is a high prevalence of pig trypanosomosis in Anambra, Benue, Oyo, Enugu, Taraba, Ebonyi and Adamawa States (Onah, 1991; Omotainse et al., 2000; Onah and Ebenebe, 2003; Anene et al., 2011; Nwanta et al., 2011; Ademola and Onyiche, 2013; Karshima et al., 2016). Pigs are important sources of blood meal for tsetse flies, especially Glossina palpalis, with the consequence of high infection rates for porcine trypanosomosis caused by T. brucei in Northern Nigeria (Karshima et al., 2016).

Although natural cases of $T$. simiae infection have not been recently reported in pigs in Glossina-infested locations of the country, a study revealed the molecular identification of $T$. simiae in tsetse flies in Northern Nigeria (Isaac et al., 2016). More than a decade ago, T. simiae infection mixed with Babesia trautmanni was reported in Mopa, Kwara State, in a unit of 131 pigs among commercial farms of more than 2000 pigs (Ocholi et al., 1988). The pigs also had coccidium, Oesophagostomum dentatum and Ascaris suum infections, making the outbreak very complicated and fatal. Outbreak of T. brucei infections in Nsukka, Anambra State, was fatal during relapse infection after diminazene aceturate treatment and was characterized by cerebral invasion of trypanosomes (Onah and Uzoukwu, 1991). Infection with T. brucei was more severe in pigs with decreasing dietary energy level (Fagbemi et al., 1990). The effect of infection was also more severe in young pigs on a low energy diet than those on a high energy one (Otesile et al., 1991b). Furthermore, the infected pigs on the low energy diet had delayed recovery after therapy (Otesile et al., 1992), suggesting that inadequate energy and other nutritional factors might be contributing to the pathogenic effects of T. brucei (Igbokwe, 1995).

The prevalence of infection was higher with $T$. brucei than with $T$. congolense, but mixed infections of both species were most common (Onah, 1991; Omeke, 1994). In cross-sectional studies, trypanosome infections were more prevalent in the rainy season than in the dry one, and prevalences were $31 \%$ of 150 pigs (Onah, 1991) and 27\% of 1954 pigs (Omeke, 1994). Sometimes, parasitemic pigs were asymptomatic (Onah, 1991). Omeke (1994) also showed that a number of subpatent cases were confirmed to have trypanosome infections by mice inoculation tests.

The role of pigs as reservoir hosts for trypanosomes infecting humans has received attention. The prevalence of $T$. brucei gambiense among pigs points to their importance as reservoirs of human infective trypanosomes in both Northern and Southern Nigeria (Onah and Ebenebe, 2003).

\section{BABESIOSIS AND EPERYTHROZOONOSIS}

Babesiosis is a hemoprotozoan disease caused by intra-erythrocytic Babesia spp. which elicits mainly intravascular hemolysis and anemia. Eperythrozoonosis is caused by another parasite of the blood, Eperythrozoon (Mycoplasma) spp., which belongs to the order Mycoplasmatales. The disease is characterized by hemolytic anemia in stressed pigs. The blood parasites identified in local and exotic pigs in Ibadan, Oyo State, were B. trautmanni, B. perroncitoi, E. suis and $E$. parvum, occurring as single or mixed infections of generally low parasitemia (Dipeolu et al., 1982), with E. suis being the most predominant among these blood parasites in the location. A previous survey in Ibadan reported that $9 \%$ of 135 pigs had B. trautmanni in blood smears (Okon, 1976). The pigs infected with $E$. suis alone, $B$. trautmanni alone or E. suis and B. trautmanni had fever and anemia (Dipeolu et al., 1983a; 1983b). In Makurdi, Benue State, Eperythrozoon spp. (5\%) and Babesia spp. (2\%) were identified in the blood smears of 351 pigs (Ogbaje et al., 2015). Sometimes, porcine babesiosis occurred concurrently with trypanosomosis as reported in Kwara State (Ocholi et al., 1988). Human eperythrozoonosis transmitted from animals has not been reported in Nigeria, but the zoonotic transmission of Eperythrozoon spp. from pigs to humans has been reported from Croatia and China according to a systematic review by Huang et al. (2012).

\section{GASTROINTESTINAL PARASITISM}

The species of gastrointestinal parasites of pigs reported in various States of Nigeria are summarized in Table II. Nematodes, cestodes, trematodes and protozoa are among the common parasites (Ikeme, 1970; Ikeme and Nduaka, 1974). In Plateau State, pigs have been infected by various species of gastrointestinal parasites (Fabiyi, 1979; Salifu et al., 1990; Gagman et al., 2015). High parasite burdens from nematodes and protozoa were reported in Rivers State (Salifu et al., 1990). Helminths and coccidia have also been reported to affect pig production in Enugu, Adamawa, Anambra, Kaduna and Ebonyi States (Nwanta et al., 2011). Helminths deprive pigs of nutrients, cause tissue injury and lead to weight loss, thereby increasing the time to attain market size. It is notable that Ascaris suum has been shown to cause visceral larva migrans in humans and pigs, allergic enteritis and intestinal obstruction in pigs, alongside other complications (Sakakibara et al., 2002; Stewart and Hoyt, 2006; Karanja et al., 2011). Visceral larva migrans causes excessive scarring of the lungs and liver, leading to offal condemnation in the abattoir. In addition, Trichuris suis, Strongyloides ransomi and Oesophagostomum spp. have been 


\section{Table II}

Gastrointestinal parasites of pigs and the States in Nigeria where they were reported

\begin{tabular}{|c|c|c|c|}
\hline Parasites & \multicolumn{2}{|l|}{ States } & References \\
\hline \multicolumn{4}{|l|}{$\begin{array}{l}\text { Nematodes } \\
\text { Ascaris suum } \\
\text { Ascaris lumbricoides } \\
\text { Ascarops strongylina } \\
\text { Ancylostoma duodenale } \\
\text { Bourgelatia diducta } \\
\text { Globocephalus spp. } \\
\text { Hyostrongylus rubidus } \\
\text { Metastrongylus spp. } \\
\text { Necator spp. } \\
\text { Oesophagostomum spp. } \\
\text { Physocephalus sexalatus } \\
\text { Stephanurus dentatus } \\
\text { Strongyloides spp. } \\
\text { Trichuris trichiura } \\
\text { Trichuris suis }\end{array}$} \\
\hline $\begin{array}{l}\text { Cestodes } \\
\text { Cysticercus cellulosae } \\
\text { Cysticercus tenuicollis } \\
\text { Echinococcus granulosus } \\
\text { Spirometra erinacei } \\
\text { Taenia spp. }\end{array}$ & \multicolumn{2}{|c|}{ Adamawa, Plateau, Oyo, Enugu, Kebbi } & $\begin{array}{l}\text { Ikeme, 1970; Fabiyi, 1979; Onah and } \\
\text { Chiejina, 1995; Faleke and Ogundipe, 2003; } \\
\text { Gweba et al., 2010; Biu and ljudai, 2012; } \\
\text { Weka et al., } 2013\end{array}$ \\
\hline \multicolumn{4}{|l|}{$\begin{array}{l}\text { Trematodes } \\
\text { Fasciola spp. } \\
\text { Fasciolopsis buski } \\
\text { Paragonimus westermani } \\
\text { Schistosoma suis }\end{array}$} \\
\hline \multicolumn{4}{|l|}{$\begin{array}{l}\text { Protozoa } \\
\text { Entamoeba spp. } \\
\text { Balantidium spp. } \\
\text { Cryptosporidium spp. } \\
\text { Eimeria spp. } \\
\text { Giardia lamblia } \\
\text { Isospora spp. }\end{array}$} \\
\hline $\begin{array}{l}\text { associated with circulatory anor } \\
\text { lial (lymphoid) hyperplasia, an } \\
\text { with lesions that hinder absorpti } \\
\text { whereas Ascarops strongylina, } \\
\text { cephalus sexalatus have been in } \\
\text { in pigs (Stewart and Hoyt, 2006; } \\
\text { iting, anorexia and depression. } \\
\text { serve as alternative hosts for Anc } \\
\text { that affects humans (Salifu et a } \\
\text { sis and risk of human teniasis h } \\
\text { Enugu State (Onah and Chiejina } \\
\text { al., 2010), Oyo State (Faleke an } \\
\text { (Biu and Ijudai, 2012), and Jos } \\
\text { Trematodes of pigs in the count } \\
\text { notic infections, but there are re } \\
\text { asis in several parts of the world }\end{array}$ & $\begin{array}{l}\text { atrophy, crypt epithe- } \\
\text { nodular typhlocolitis, } \\
\text { causing unthriftiness, } \\
\text { s rubidus and Physo- } \\
\text { a-suppurative gastritis } \\
\text { 2011) leading to vom- } \\
\text { s have been shown to } \\
\text { lenale, the hookworm } \\
\text { ia solium cysticerco- } \\
\text { ted in Nsukka area of } \\
\text { Kebbi State (Gweba et } \\
\text { 003), Adamawa State } \\
\text { (Weka et al., 2013). } \\
\text { en implicated in zoo- } \\
\text { ses involving fascioli- } \\
\text { ukambagire, 2015). }\end{array}$ & \multicolumn{2}{|c|}{$\begin{array}{l}\text { ECTOPARASITISM } \\
\text { Ectoparasites such as lice, fleas and mites have been reported to affect } \\
\text { pigs in Oyo, Kwara, Kaduna, Adamawa, Enugu, Anambra, Ebonyi, } \\
\text { Plateau and Rivers States (Dipeolu and Sellers, 1970; Olufemi, 1989; } \\
\text { Oladele, 2002; Ironkwe and Amefule, 2008; Dogo et al., 2010; Nwanta } \\
\text { et al., 2011). Lice and fleas act as vectors of disease organisms and, } \\
\text { with mites, often trigger severe itching that makes animals unable to } \\
\text { feed and grow well. In rural areas, pigs, particularly those that are } \\
\text { extensively managed, are the most important reservoirs of Tunga pen- } \\
\text { etrans (jigger flea) that affects humans (Ugbomoiko et al., 2008). In } \\
\text { Imo State, 18\% of } 66 \text { pigs were affected by mange (Opara et al., 2007). } \\
\text { The prevalence of mite infestation was 77\% in Benue State (Gboko), } \\
\text { but } 43 \% \text { had mange lesions (Ior, 2009). Demodex mange occurred in } \\
20 \% \text { of } 351 \text { pigs in Enugu State (Nwanta et al., 2011). Mite infections } \\
\text { (scabies) of pigs may be transmitted to animal handlers and butchers. }\end{array}$} \\
\hline
\end{tabular}




\section{DISEASE BURDEN: ISSUES AND CHALLENGES}

A pertinent issue confronting pig production and health management in Nigeria is the religious restriction under the Sharia and Judaic norms. In most parts of Northern Nigeria and in some in Southern Nigeria, religious laws forbid contact with pigs and pig products, consumption of pork and promotion of businesses related to the pig production industry. This context excludes large populations of farmers, health givers and policy regulators averse to pig-related issues. In the universities and research institutes located in these areas, almost no attention is given to piggery and the challenges facing the sector are treated with levity. The major pig production arena is, therefore, in Southern Nigeria and, to a lesser extent, in the Middle Belt and savanna areas of Northern Nigeria. Without adequate veterinary resources and health services to pig populations reared in the country, the sustainability and expansion of the industry may not be maintained in the long run. The policy framework for pig farming and their health management system is ill-defined and even experts in the field can barely articulate it for implementation. Thus, diseases of pigs as reported in various parts of Nigeria (Tables I and II) may not be under strict national surveillance and few, if any, abattoirs designated for pig slaughter are under mandatory government supervision through the instrument of meat inspection and veterinary personnel who control and report unwholesome pig products or diseases. On-farm investigation of diseases is often not conducted and farmers engage in self-help in the face of challenging health issues and, in some instances, there are reports that sick animals are sold or slaughtered for consumption with the risk of spreading infections from animals to human populations (Fasina et al., 2010).

Inadequate laboratory services for disease investigations also militate against the efforts toward disease diagnosis and surveillance (Igbokwe, 2011) and most important disease investigations need to be conducted in foreign laboratories with the aid of international agencies (Odemuyiwa et al., 2000). Several diseases were rarely reported and were discountenanced in this review because their identifications through syndromic or laboratory methods by veterinary personnel were not validly verifiable. They include swine flu, swine erysipelas, salmonellosis, pasteurellosis, tuberculosis, leptospirosis, swine pox, rabies and anthrax. Poor quality diagnostic output and, perhaps inaccurate laboratory diagnosis may be in contention; but adequate training and retraining, and quality control measures are issues that also need to be addressed to ensure that the disease surveillance system is robust and can face the demands of shielding the population from risks of epidemic diseases.

Piglet mortality rates of $15.0 \%$ were reported in the Southeast (Nwanta et al., 2011), 18.6\% in the North-Central (Rekwot et al., 2003); they were $29.3 \%$ and $44.8 \%$ for exotic and indigenous breeds, respectively (Uko et al., 1994). The causes of piglet deaths were not fully investigated but were largely attributed to low birth weights (Uko et al., 1994). Neonatal health and prevention of infertility and abortions in herds are paramount and appropriate initiative for growth of the pig population in the country.

This review identified reports involving diseases that undermine reproductive health, feed conversion efficiency and growth. African swine fever and trypanosomosis are particularly fatal to pigs and need to be controlled. It is costly to the production system when there is failure to control African swine fever and trypanosomosis (Fadiga et al., 2013). As there are no effective vaccines against these diseases (Fadiga et al., 2013), regular testing and sustained surveillance for disease outbreaks will help in disease control. Vector control using screens, insecticides and bush clearing are part of a trypanosomosis control program (Fadiga et al., 2013). Multidrug resistance in the chemotherapy of trypanosomosis, which leads to treatment failures and relapse of infections, is an intractable challenge (Onah and Uzoukwu, 1991). In addition, the adverse effects of gastrointestinal parasites can be avoided with an effective strategic therapeutic program (Salifu et al., 1990).

There is inadequate application of on-farm biosecurity in piggeries in Nigeria, even though the implementation of on-farm biosecurity is cheaper and more effective than treatment or inaction in the control of diseases (Fasina et al., 2012; Fadiga et al., 2013) and has a significant impact on reducing the incidence of outbreaks on farms (Saka et al., 2010; Maduka et al., 2016). Poor biosecurity practices increase the risk of African swine fever outbreaks (Fasina et al., 2010), but cleaning piggeries without applying other biosecurity protocols is not sufficient to exclude pig parasitic diseases because of outdoor scavenging (Salifu et al., 1990). Raising pigs alongside other animal species such as domestic fowls, poultry, goats and sheep is a common practice in Kaduna, Enugu, Anambra and Ebonyi States (Nwanta et al., 2011) and these other species might be sources of infections. Since there have been outbreaks of avian influenza in Nigeria, there is the potential danger of influenza virus undergoing mutation in pigs as 'mixing vessel'. In fact, there are confirmed reports of isolation of variant strains of influenza virus from pigs in Nigeria (Adeola et al., 2009; Meseko et al., 2014; 2018). This scenario poses a danger for zonootic outbreak of influenza. In addition, there are risks of zoonoses from the spread of trypanosomiasis, brucellosis, eperythrozoonosis, larva migrans, cryptosporidiosis, balantidiasis, ancylostomosis, entamoebosis, teniasis, fascioliasis, jigger fleas and mange to human populations, but the medical epidemiology of most of these zoonoses in Nigeria has been rarely investigated and is not reported (Coker et al., 2000).

In intensive pig farming, adequate nutrition may support immunity and improve resistance to diseases or increase the performance of pigs even with disease burden. The nutritional challenges emerge when feed costs are high and capital outlay cannot accommodate a balanced nutrition. Farmers may make ad hoc feeds that are not sustainable for the production system and, sometimes, may encounter feed-related poisoning (Daniel-Igwe, 2014), and undernutrition or nutritional imbalance. Diagnosis of nutritional diseases is difficult and losses from nutritional inadequacies may be imperceptible until it is catastrophic. Recent outcries of farmers concerning the increasing feed cost and disease burden call for urgent efforts to rescue the pig production industry through systematic government intervention, so as to enable farmers to meet increasing demands for pig and pork products across West Africa (Akinfenwa, 2017). The control of diseases, especially transboundary diseases, is geared toward encouraging international trade to boost market for the national pig industry.

\section{CONCLUSION}

Although the pig population in Nigeria has been growing in the previous two decades, the growth would have been much more improved without the challenges of disease burdens such as African swine fever, foot-and-mouth disease, brucellosis, endoparasitisms involving hemoparasites and gastrointestinal parasites, and ectoparasitisms as concisely reviewed. The technical surveillance of diseases and reporting systems to health authorities (in charge of disease control) ought to be strengthened. Health extension workers need to work with the farmers in the areas of biosecurity and strategic health planning. Government policies in the pig sector could be re-examined for suitability, effectiveness and sustainability in meeting the demands of the current challenges. Veterinary training on pig health in the country should be re-emphasized, and researches into diseases of pigs that adversely affect pig production need to be funded by appropriate government agencies. The zoonotic risk assessment of pig production systems to the health of human populations, in contact with services and products of the industry, requires adequate attention. This review has identified the following infections/infestations of pigs in 
parts of Nigeria which could be transmitted to humans: influenza, trypanosomosis, brucellosis, eperythrozoonosis, larva migrans, cryptosporidiosis, balantidiasis, ancylostomosis, entamoebosis, teniasis, jigger fleas and mange. The health system for pig production deserves professional input from experts, mobilizing one-health outlook that involves synergy of veterinary and human health policy formulation and application (Halliday et al., 2015; Okello et al., 2015). Ultimately, the national priority in surveillance and control of diseases, aimed at supporting pig production, requires improved diagnostic capacities, tight monitoring of disease burden and supervised control measures.

\section{Acknowledgments}

Authors are working under the self-funded initiatives of the Strategic Animal Research Group of the University of Maiduguri.

\section{REFERENCES}

Abiola J.O., Omotosho O.O., Adeniyi O.M., Ayoade G.O., 2015. Sociodemographic characteristics of swine producers and swine management practices in Ibadan, Oyo State, Nigeria. Alex. J. Vet. Sci., 47 (1): 18-23, doi: 10.5455/ajvs.188832

Abwage S.A., Umaru G.A., Musa Y.B., Adamu Z., Akensire U.A., Njobdi A.B., Bello O.A., 2015. Detection of African swine fever virus (ASFV) antibodies in pigs in Taraba State, Northeast Nigeria. Sokoto J. Vet. Sci.,13 (2): 20-25, doi: 10.4314/sokjvs.v13i2.4

Ademola I.O., Onyiche T.E., 2013. Haemoparasites and haematological parameters of slaughtered ruminants and pigs at Bodija abattoir, Ibadan, Nigeria. Afr. J. Biomed. Res., 16 (2): 101-105

Adenaike E.A., Tekdek L.B., Kazeem H.M., Umoh J.U., Simon A.Y., 2016. African swine fever antibody detection and status pigs in Sabon Gari Local Government area of Kaduna State, Nigeria. J. Anim. Prod. Res., 28 (2): 126134

Adeola O.A., Adeniji J.A., Olugasa B.O., 2009. Isolation of Influenza A viruses from pigs in Ibadan, Nigeria. Vet. Ital., 45 (3): 383-390

Agu W.E., Bajeh Z.T., 1986. An outbreak of fatal Trypanosoma brucei brucei infection in Benue State of Nigeria. Trop. Vet., 4: 25-28

Aiki-Raji C.O., Oluwayelu D.O., Adeyemo I.A., Adebiyi A.I., 2016. Seroprevalence of foot-and-mouth disease in slaughtered pigs in Ibadan, Southwest Nigeria. Alex. J. Vet. Sci., 48 (2): 18-22, doi: 10.5455/ajvs.199130

Ajala M.K., Adesehinwa A.O.K., 2008. Analysis of pig marketing in Zango Kataf local government area of Kaduna State, Nigeria. Tropicultura, 26 (4): 229239

Ajala M.K., Adesehinwa A.O.K., Bawa G.S., 2006. Socio-economic factors influencing swine management practices among women in Jama'a local government area of Kaduna State, Nigeria. Trop. Subtrop. Agroecosyst., 6 (2): 43-48

Akinfenwa G., 2017. Pig farmers cry out over diseases, high cost. https:/t. guardian.ng/features/pig-farmers-cry-out-over-diseases-high-cost/\#top (accessed 28 May 2017)

Alexandersen S., Mowat N., 2005. Foot-and-mouth disease: host range and pathogenesis. In: Foot-and-mouth disease virus (Ed: Mahy B.W.J.). Curr. Top. Microbiol. Immunol., 288: 9-42, doi: 10.1007/3-540-27109-0_2

Allam L., Ogwu D., Agbede R.I.S., Sackey A.K.B., 2011. Hematological and serum biochemical changes in gilts experimentally infected with Trypanosoma brucei. Vet. Arhiv., 81 (5): 597-609

Anene B.M., Ifebigh A.O., Igwilo I.A., Umeakuana P.U., 2011. Prevalence and haemato-biochemical parameters of trypanosome-infected pigs at Nsukka, Nigeria. Comp. Clin. Pathol., 20 (1): 15-18, doi: 10.1007/s00580-009-0944-2

Anukwu M.I., Ebong V.O., 2011. Analysis of the performance of piggery loan beneficiaries in the integrated farmers scheme of Akwa Ibom State: a case of Uyo agricultural zone. Niger. J. Agric. Food Environ.,7 (3): 73-79

Aworh M.K., Okolocha E., Kwaga J., Fasina F., Lazarus D., Suleman I., Poggensee G., et al., 2013. Human brucellosis: seroprevalence and associated exposure factors among abattoir workers in Abuja, Nigeria-2011. Pan. Afr. Med. J., 16, 103, doi: 10.11604/pamj.2013.16.103.2143

Awosanya E.J., Olugasa B., Ogundipe G., Grohn Y.T., 2015. Seroprevalence and risk factors associated with African swine fever on pig farms in Southwest Nigeria. BMC Vet. Res., 11, 133, doi: 10.1186/s12917-015-0444-3
Ayas S.A., Bot C.J., Jambol A.R., Luka P.D., 2016. Molecular detection of African swine fever virus in apparently healthy domestic pigs in Nasarawa State, Nigeria. Sokoto J. Vet. Sci., 14 (3): 26-31, doi: 10.4314/sokjvs.v14i3.4

Ayoade G.O., Adeyemi I.G., 2003. African swine fever: an overview. Rev. Elev. Med. Vet. Pays Trop., 56 (3-4): 129-135, doi : 10.19182/remvt.9853

Babalobi O.O., Olugasa B.O., Oluwayelu D.O., Ijagbone I.F., Ayoade G.O., Agbede S.A., 2007. Analysis and evaluation of mortality losses of the 2001 African swine fever outbreak, Ibadan, Nigeria. Trop. Anim. Health Prod., 39 (7): 533-542, doi: 10.1007/s11250-007-9038-9

Bale O.O.J., Nuru S., 1985. Swine brucellosis: bacteriological and serological investigation of naturally infected pigs from six piggeries in Northern Nigeria. J. Anim.Prod. Res., 5: 193-199

Bawa G.S., Balogun T.F., Ega L., Omage J.J., 2004. Urban backyard swine production: a case study of Kaduna, a Nigerian metropolitan city. Niger. J. Anim. Prod., 31: 237-244

Bello-Onaghise G., Vaikosen S.E., Evivie S.E., 2012. Abortion cases in pig farms in Benin City and some surrounding communities in Edo State, Nigeria. Niger. J. Agric. Food Environ., 8 (4): 37-42

Biu A.A., ljudai J., 2012. Prevalence and morphometric studies on porcine cystercercosis in Adamawa State, Nigeria. Sokoto J. Vet. Sci., 10 (1): 28-31, doi: 10.4314/sokjvs.v10i1.6

Bourn D., Wint W., Blench R., Woolley E., 1994. Nigerian livestock resources survey. (FAO) World Anim. Rev., 78 (1): 49-58

Cadmus S.I.B., ljagbone I.F., Oputa H.E., Adesokan H.K., Stack J.A., 2006. Serological survey of brucellosis in livestock animals and workers in Ibadan, Nigeria. Afr. J. Biomed. Res., 9 (3): 163-168, doi: 10.4314/ajbr.v9i3.48900

Coker A.O., Isokpehi R.D., Thomas B.N., Fagbenro-Beyioku A.F., Omilabu S.A., 2000. Zoonotic infections in Nigeria: overview from a medical perspective. Acta Trop., 76 (1): 59-63, doi: 10.1016/S0001-706X(00)00091-7

Daniel-Igwe G., 2014. Hepatic necrosis and degenerative myopathy associated with cassava feeding in pigs. J.Vet. Med., 2014, 584945, doi: $10.1155 / 2014 / 584945$

Dipeolu O.O., Majaro O.M., Akinboade O.A., Nwufor K.J., 1982. Studies on the blood parasites of pigs in Ibadan, Nigeria. Vet. Parasitol., 10 (1): 87-90, doi: 10.1016/0304-4017(82)90011-5

Dipeolu O.O., Otesile E.B., Adetunji A., Fagbemi B.O., 1983a. Studies on blood parasites of pigs in Nigeria: pathogenicity of Babesia trautmanni in experimentally infected pigs. Zoonoses Public Health, 30 (1-10): 97-102, doi: 10.1111/j.1439-0450.1983.tb01817.x

Dipeolu O.O., Otesile E.B., Fagbemi B.O., Adetunji A., 1983b. Pathogenicity of Eperythrozoonsuis alone and when mixed with Babesia trautmann in experimentally-infected pigs. Vet.Parasitol., 13 (2): 127-134, doi: 10.1016/0304-4017(83)90072-9

Dipeolu O.O., Sellers K.C., 1970. Investigation of the ectoparasites of indigenous pigs in a rural area of Southwest Nigeria. Bull. Anim. Health Prod. Afr., 25: 142-148

Dogo G.I., Ogunsan E.A., Tanko T.J., Kamani J., Tafarki A.E., Nnabuife H.E., Peters J., 2010. Further evaluation of field efficacy of Scabicur lotion in the control of mange and ectoparasites in domestic animals in Nigeria. Vom J. Vet. Sci., 7: 23-25

Ducrotoy M.J., Bertu W.J., Ocholi R.A., Gusi A.M., Bryssinckx W., Welburn S., Moriyon I., 2014. Brucellosis as an emerging threat in developing economies: lessons from Nigeria. PLoS Negl. Trop. Dis., 8 (7): e3008, doi: 10.1371/journal.pntd.0003008

Fabiyi J.P., 1979. Helminths of the pig on the Jos Plateau, Nigeria: relative prevalence, abundance and economic significance. I. Helminthol., 53 (1): 65-71, doi: 10.1017/S0022149X00005757

Fadiga M., Jost C., Ihedioha J., 2013. Financial costs of disease burden, morbidity and mortality from priority livestock diseases in Nigeria. Disease burden and cost-benefit analysis of targeted interventions. ILRI Research Report 33. ILRI, Nairobi, Kenya.https://cgspace.cgiar.org/bitstream/ handle/10568/33418/ResearchReport_33.pdf?sequence=2 (accessed 18 May 2017)

Fagbemi B.O., Otesile E.B., Makinde M.O., Akinboade O.A., 1990. The relationship between dietary energy levels and the severity of Trypanosoma brucei infection in growing pigs. Vet. Parasitol., 35 (1-2): 29-42, doi: 10.1016/0304-4017(90)90114-Q

Fakai L.U., Faleke O.O., Magaji A.A., Ibitoye E.B., Alkali B.R., 2015. Seroprevalence of foot-and-mouth disease virus infection in pigs from Zuru, Nigeria. Vet. World, 8 (7): 865-869, doi: 10.14202/vetworld.2015.865-869

Faleke O.O., Ogundipe G.A.T., 2003. Taenia solium cysticercosis and human taeniasis in Oyo State, Nigeria. Niger. Vet. J., 24 (3): 60-64 
Fasina F.O., Lazarus D.D., Spencer B.T., Makinde A.A., Bastos A.D.S., 2012 Cost implications of African swine fever in smallholder farrow-to-finish units: Economic benefits of disease prevention through biosecurity. Transbound. Emerg.Dis., 59 (3): 244-255, doi: 10.1111/j.1865-1682.2011.01261.x

Fasina F.O., Shamaki D., Makinde A.A., Lombin L.H., Lazarus D.D., Rufai S.A., Adamu S.S., et al., 2010. Surveillance for African swine fever in Nigeria, 2006-2009 (2010). Transbound. Emerg. Dis., 57 (4): 244-253, doi 10.1111/j.1865-1682.2010.01142.x

Gagman H.A., Ajayi O.O., Yusuf A.S., 2015. Survey of gastro-intestina protozoans of pigs slaughtered at the Jos Abattoir, Plateau State, Nigeria. Bayero J. Pure Appl. Sci., 8 (1): 96-100, doi: 10.4314/bajopas.v8i1.17

Gusi A.M., Bertu W.J., Mwankwon E.S., Hassan M., Ocholi R.A., Bot C.J., Ayuba N.J., et al., 2010. Prevalence of Brucella antibodies in animals and butchers at Jos abattoir, Nigeria. Vom J. Vet. Sci., 7: 30-34

Gweba M., Faleke O.O., Junaidu A.U., Fabiyi J.P., Fajinmi A.O., 2010. Some risk factors for Taenia solium cysticercosis in semi-intensively raised pigs in Zuru, Nigeria. Vet. Ital., 46 (1): 57-67

Halliday J.E., Allan K.J., Ekwem D., Cleaveland S., Kazwala R.R., Crump J.A., 2015. Endemic zoonoses in the tropics: a public health problem hiding in plain sight. Vet. Rec., 176 (9): 220-225, doi: 10.1136/vr.h798

Huang D.S., Guan P., Wu W., Shen T.F., Liu H.L., Cao S., Zhou H., 2012. Infection rate of Eperythrozoon spp. in Chinese population: a systematic review and meta-analysis since the first Chinese case reported in 1991. BMC Infect. Dis., 12, 171, doi: 10.1186/1471-2334-12-171

Igbokwe I.O., 1995. Nutrition in the pathogenesis of African trypanosomiasis. Protozool. Abstr., 19 (12): 797-807

Igbokwe I.O., 2011. Laboratory investigation in veterinary practice: full text. https://doi.org/10.13140/RG.2.2.21555.02088 (accessed 2 June 2017)

Ikeme M.M., 1970. Pig parasites of Nigeria with emphasis on the local breed. Vet. Rec., 86 (21): 644

Ikeme M.M., Nduaka O., 1974. Pig parasites of Nigeria. III. Local pig industries in Plateau area of Northern Nigeria and their helminth problems at the peak of rains. Bull. Epizoot. Dis. Afr., 22 (4): 348-355

Ilemobade A.A., Balogun T.F., 1981. Pig trypanosomiasis: effects of infection on feed intake, liveweight gain and carcass traits. Trop. Anim. Health Prod., 13 (3): 128-136, doi: 10.1007/BF02237909

Ior D., 2009. Prevalence of sarcoptic mange in Gboko area of Benue State, Nigeria. In: 14th Annual Conf. Animal Science Association of Nigeria, Ogbomosho, Nigeria, 14-17 Sept. 2009

Ironkwe M.O., Amefule K.U., 2008. Appraisal of indigenous pig production and management practices in Rivers State, Nigeria. J. Agric. Soc. Res., 8 (1): 1-7, doi: 10.4314/jasr.v8i1.2878

Isaac C., Ciosi M., Hamilton A., Scullion K.M., Dede P., Igbinosa I.B., Nmorsi O.P.G., et al., 2016. Molecular identification of different trypanosome species and subspecies in tsetse flies of Northern Nigeria. Parasit. Vectors, 9 (1), 301, doi: 10.1186/s13071-016-1585-3

Isoun T.T., 1968. The pathology of Trypanosoma simiae infection in pigs. Ann. Trop. Med. Parasitol., 62 (2): 188-192, doi: 10.1080/00034983. 1968.11686549

Karanja D.N., Ngatia T.A., Wabacha J.K., Bebora L.C., Ng'ang'a C.J., 2011. Pathogenic effects associated with natural gastrointestinal helminth infections in pigs in Kenya. Bull. Anim. Health Prod. Afr., 59 (1): 53-59, doi: 10.4314/ bahpa.v59i1.68408

Karshima S.N., Lawal I.A., Okubanjo O.O., 2016. Feeding patterns and xeno monitoring of trypanosomes among tsetse flies around the GashakaGumti National Park in Nigeria. J. Parasitol. Res., 2016, 1591037, doi: 10.1155/2016/1591037

Kitching R.P., Alexandersen S., 2002. Clinical variation in foot-and-mouth disease: pigs. Rev. Sci. Tech. Off. Int. Epizoot., 21 (3): 513-518, doi: 10.20506/rst.21.3.1367

Machebe N.S., Onyekuru N.A., Ekweogu N., 2009. Socio-economic factors affecting pig production in Enugu State, Nigeria. J. Agric. For. Soc. Sci., 7 (1): 41-49

Maduka C.V., Igbokwe I.O., Atsanda N.N., 2016. Appraisal of chicken production with associated biosecurity practices in commercial poultry farms located in Jos, Nigeria. Scientifica, 2016, 1914692, doi: $10.1155 / 2016 / 1914692$

Mailafia S., Iliya J.B., 2009. African swine fever outbreak in Kumo, Nigeria: a case report. Niger. Vet. J., 29 (4): 53-57
Majiyagbe K.A., Shamaki D., Luther N.J., Udeani T.K.C., 2004. African swine fever epidemics. The Nigerian experience, 1997-2004. Vom J. Vet. Sci., 1 (1): 138-147

Meseko C., Globig A., ljomanta J., Joannis T., Nwosuh C., Shamaki D., Harder T., et al., 2018. Evidence of exposure of domestic pigs to highly pathogenic avian influenza H5N1 in Nigeria. Sci. Rep., 8: 5900, doi: 10.1038/s41598018-24371-6

Meseko C.A., Odaibo G.N., Olaleye D.O., 2014. Detection and isolation of 2009 pandemic influenza A/H1N1 virus in commercial piggery, Lagos Nigeria. Vet. Microbiol., 168 (1): 197-201, doi: 10.1016/j. vetmic.2013.11.003

Nawathe D.R., Goni M., 1976. Foot-and-mouth disease in Nigeria. Bull. Anim. Health Prod. Afr., 24 (1): 1-4

Ngbede E.O., Momoh A.H., Bala R.S., Madaki B.D., Maurice N.A., 2013. An abattoir-based study on serodiagnosis of swine brucellosis in Makurdi, Benue State, North-Central Nigeria. J. Adv. Vet. Res., 3 (2): 57-59

Nwanta J.A., Shoyinka S.V.O., Chah K.F., Onunkwo J.I., Onyenwe I.W., Eze J.I., Iheagwam C.N., et al., 2011. Production characteristics, disease prevalence, and herd-health management of pigs in Southeast Nigeria. J. Swine Health Prod., 19 (6): 331-339

Nyindo M., Lukambagire A.H., 2015. Fasciolasis: an ongoing zoonotic trematode infection. BioMed Res. Int., 2015, 786195, doi: 10.1155/2015/ 786195

Ocholi R.A., Ezeugwu R.U., Nawathe D.R., 1988. Mixed outbreak of trypanosomiasis and babesiosis in pigs in Nigeria. Trop. Anim. Health Prod., 20 (3): 140, doi: 10.1007/BF02240078

Odemuyiwa S.O., Adebayo I.A., Ammerlann W., Ajuwape A.T.P., Alaka O.O., Oyedele O.I., Soyelu K.O., et al., 2000. An outbreak of African swine fever in Nigeria: virus isolation and molecular characterization of VP 72 gene of a first isolate from West Africa. Virus Genes, 20 (2): 139-142, doi: 10.1023/A:1008118531316

Ogbaje C.I., Mbatsorun T.I., Victor I., 2015. Survey of haemoparasites of pigs in major pig markets/farms in Mahurdi metropolis. Niger. Vet. J., 36 (1): 11301134

Okello A., Welburn S., Smith J., 2015. Crossing institutional boundaries: mapping the policy process for improved control of endemic and neglected zoonoses in sub-Saharan Africa. Health Policy Plan., 30 (6): 804-812, doi: 10.1093/heapol/czu059

Okon E.D., 1976. Blood parasites of local pigs in Ibadan. Trop. Anim. Health Prod., 8 (1): 96, doi: 10.1007/BF02383377

Oladele O.I., 2002. Farmers feedback on pig production technology in Kwara State, Nigeria. J. Livest. Res. Rural Dev., 14 (5), 50, http://lrrd.cipav.org.co/ Irrd14/5/olad145.htm (accessed 13 may 2017)

Olufemi B.E., 1989. Porcine sarcoptes mange (Sarcoptes scabiei var suis) in Ibadan, Nigeria. Niger. J. Anim.Prod.,16 (1): 61-63

Olugasa B.O., ljagbone I.F., 2007. Pattern of spread of African swine fever in south-western Nigeria, 1997-2005. Vet. Ital., 43 (3): 621-628

Omeke B.C.O., 1994. Pig trypanosomiasis: prevalence and significance in endemic Middle Belt zone of Southern Nigeria. Rev. Elev. Med. Vet. Pays Trop., 47 (4): 381-386, doi: 10.19182/remvt.9076

Omeke B.C.O., Ugwu D.O., 1991. Pig trypanosomiasis: comparative anaemia and histopathology of lymphoid organs. Rev. Elev. Med. Vet. Pays Trop., 44 (3): 267-272, doi: 10.19182/remvt.9164

Omotainse S.O., Edeghere H., Omoogu G.A., Elhassan E.O., Thompson G., Igweh C.A., Ukah J.A.C., et al., 2000. The prevalence of animal trypanosomiasis in Konshisha Local Government Area of Benue State, Nigeria. Isr. J. Vet. Med., 55 (4): 142-143

Onah D.N., 1991. Porcine trypanosomiasis in Nigeria: infections in local and exotic pigs in the Nsukka area of Anambra State. Trop. Anim. Health Prod., 23 (3): 141-146, doi: 10.1007/BF02356992 [see also corrigendum: https:// link.springer.com/article/10.1007/BF02361199]

Onah D.N., Chiejina S.N., 1995. Taenia solium cysticercosis and human taeniasis in the Nsukka area of Enugu State, Nigeria. Ann. Trop. Med. Parasitol., 89 (4): 399-407, doi: 10.1080/00034983.1995.11812968

Onah D.N., Ebenebe O.O., 2003. Isolation of a human serum-resistant Trypanosoma brucei from a naturally infected pig in the Nsukka area of Enugu State. Niger. Vet. J., 24 (1): 37-43, doi: 10.4314/nvj.v24i1.3435

Onah D.N., Uzoukwu M., 1991. Porcine cerebral Trypanosoma brucei brucei trypanosomiasis. Trop. Anim. Health Prod., 23 (1): 39-44, doi: 10.1007/ BF02361268 
Onunkwo J.I., Njoga E.O., Nwanta J.A., Shoyinka S.V.O., Onyenwe I.W., Eze J.I., 2011. Serological survey of porcine Brucella infection in Southeast Nigeria. Niger. Vet. J., 32 (1): 60-62, doi: 10.4314/nvj.v32i1.68989

Opara M.N., Anukam N.C., Okoli I.C., 2007. Prevalence and hematological indices of pigs naturally infested with mange in a Nigerian university farm. Int. J. Trop. Agric. Food Syst., 1 (1): 37-41, doi: 10.4314/ijotafs.v1i1.40883

Otesile E.B., Ajuwape A.T.P., Odemuyiwa S.O., Akpavie S.O., Olaifa A.K., Odaibo G.N., Olaleye O.D., et al., 2005. Field and experimental investigations of an outbreak of African swine fever in Nigeria. Rev. Elev. Med. Vet. Pays Trop., 58 (1-2): 21-26, doi: 10.19182/remvt.9935

Otesile E.B., Akpavie S.O., Fagbemi B.O., Ogunremi A.O., 1991a. Pathogenicity of Trypanosomabrucei brucei in experimentally infected pigs. Rev. Elev. Med. Vet. Pays Trop., 44 (3): 279-282, doi: 10.19182/remvt.9167

Otesile E.B., Fagbemi B.O., Adeyemo O., 1991b. The effect of Trypanosoma brucei infection on serum biochemical parameters in boars on different planes of dietary energy. Vet. Parasitol., 40 (3-4): 207-216, doi: 10.1016/0304-4017(91)90101-Z

Otesile E.B., Fagbemi B.O., Makinde M.O., Akinboade O.A., 1992. The response of pigs experimentally infected with Trypanosoma brucei to isometamidium chloride therapy and the relation to nutrition. Vet. Q., 14 (3): 88-91, doi: 10.1080/01652176.1992.9694339

Owolodun O.A., Obishakin E.T., Ekong P.S., Yakubu B., 2010a. Investigation of African swine fever in slaughtered pigs, Plateau State, Nigeria, 2004-2006. Trop. Anim. Health. Prod., 42 (8): 1605-1610, doi: 10.1007/s11250-0109635-x

Owolodun O.A., Yakubu B., Antiabong J.F., Ogedengbe M.E., Luka P.D., John Audu B., Ekong P.S., et al., 2010b. Spatio-temporal dynamics of African swine fever outbreaks in Nigeria, 2002-2007. Transbound. Emerg. Dis., 57 (5): 330-339, doi: 10.1111/j.1865-1682.2010.01153.x

Rekwot P.I., Abubakar Y.U., Jegede J.O., 2003. Swine production characteristics and management systems of smallholder piggeries in Kaduna and Benue States of North Central Nigeria. Niger. Vet J., 24 (2): 34-40, doi: 10.4314/nvj. v24i2.3452

\section{Résumé}

Igbokwe I.O., Maduka C.V. Maladies affectant la production porcine au Nigeria : synthèse des questions et des défis actuels

L'intérêt croissant pour la production porcine, source complémentaire de protéine animale, se manifeste au Nigeria par une augmentation de la population de porcs. Dans les régions où il n'existe aucune restriction religieuse à la production et à la consommation de porc, la survenue de maladies représente la contrainte majeure à une production profitable de cochons. Les maladies importantes du porc, signalées dans les régions du pays où elles sont présentes, sont recensées dans cette synthèse. La peste porcine africaine, la fièvre aphteuse, la brucellose, la trypanosomose, la babésiose, l'épérythrozoonose, les helminthoses, les coccidioses et les autres parasitoses ont des effets négatifs sur la production (augmentation de l'indice de consommation, réduction du taux de reproduction et de la croissance) aussi bien que sur la mortalité des porcelets et des cochons adultes. Les pertes économiques causées par la charge de morbidité et les stratégies de lutte inadéquates sont des problèmes auxquels est confrontée l'industrie porcine. Les risques de diffusion de zoonoses, comme la grippe, la trypanosomiase, les larva migrans, le ténia, la gale, la cryptosporidiose, la balantidiase, I'ankylostomose, l'amibiase et la tungose (due à Tunga penetrans), à partir de porcs infectés sont réels. Il est essentiel de proposer aux éleveurs des ressources et des services vétérinaires permettant des stratégies de lutte efficaces. Il est également nécessaire de faire une révolution conceptuelle afin de développer la viabilité de la production porcine dans le pays.

Mots-clés : porcin, production animale, virose, maladie bactérienne, parasitose, maladie gastro-intestinale, morbidité, Nigeria
Robinson T.P., Wint G.R.W., Conchedda G., Van Boeckel T.P., Ercoli V. Palamara E., Cinardi G., et al., 2014. Mapping the global distribution of livestock. PLoS One, 9 (5): e96084, doi: 10.1371/journal.pone.0096084

Saka J.O., Adesehinwa A.O.K., Ajala M.K., 2010. Incidence of African swine fever (ASF) disease and its associated implications on pig production in Lagos State, Nigeria. Bulg. J. Agric. Sci., 16 (1): 80-90

Sakakibara A., Baba K., Niwa S., Yagi T., Wakayama H., Yoshida K., Kobayash T., et al., 2002. Visceral larva migrans due to Ascaris suum which presented with eosinophilic pneumonia and multiple intra-hepatic lesions with severe eosinophil infiltration. Outbreak in a Japanese area other than Kyushu. Intern. Med. 41 (7): 574-579, doi: 10.2169/internalmedicine.41.574

Salifu D.A., Manga T.B., Onyali I.O., 1990. A survey of gastrointestinal parasites in pigs of the Plateau and Rivers States, Nigeria. Rev. Elev. Med. Vet. Pays Trop., 43 (2): 193-196, doi: 10.19182/remvt.8848

Stewart T.B., Hoyt P.G., 2006. Internal parasites. In: Diseases of swine (Eds Straw B.E., Zimmerman J.J., D'Allaire S., Taylor D.J.). Blackwell, Ames, IA, USA, 901-914

Ugbomoiko U.S., Ariza L., Heukelbach J., 2008. Pigs are the most important animal reservoir for Tunga penetrans (jigger flea) in rural Nigeria. Trop. Doctor, 38 (4): 226-227, doi: 10.1258/td.2007.070352

Uko O.J., Ataja A.M., Babatunde G.M., 1994. Preliminary study of the incidence of pre-weaning mortality in exotic and West African dwarf pigs in South Nigeria. Rev. Elev. Med. Vet. Pays Trop., 47 (3): 329-332, doi: 10.19182/remvt.9097

Ularamu H.G., Ibu J.O., Wood B.A., Abenga J.N., Lazarus D.D., Wungak Y.S., Knowles N.J., et al., 2016. Characterization of foot-and-mouth disease viruses collected in Nigeria between 2007 and 2014: evidence for epidemiological links between West and East Africa. Transbound. Emerg. Dis., 64 (6): 1867-1876, doi: 10.1111/tbed.12584

Weka R.P., Ikeh E.I., Kamani J., 2013. Seroprevalence of antibodies (IgG) to Taenia solium among pig rearers and associated risk factors in Jos metropolis, Nigeria. J. Infect. Dev. Ctries, 7 (2): 67-72, doi: 10.3855/jidc.2309

\section{Resumen}

Igbokwe I.O., Maduka C.V. Carga patólogica que afecta la producción porcina en Nigeria: síntesis de problemas y desafíos actuales

El interés creciente en la producción porcina como fuente complementaria de proteína animal ha llevado al crecimiento de la población porcina en Nigeria. Los brotes de enfermedades representan la mayor limitación para la producción porcina rentable en aquellos lugares donde no existe una barrera religiosa para la producción y el consumo de carne de cerdo. En la presente revisión se destacan las enfermedades más importantes de los cerdos reportadas en el país y la ubicación de la población de cerdos afectada. La peste porcina africana, la fiebre aftosa, la brucelosis, la tripanosomosis, la babesiosis, la eperitrozoonosis, las helmintosis, las coccidiosis y otras parasitosis impactan el sistema de producción al afectar negativamente la eficiencia de la conversión alimenticia, la reproducción y las tasas de crecimiento, así como provocar mortalidad de lechones y adultos. Las pérdidas económicas debido a esta carga patógena y las estrategias de intervención inadecuadas son los problemas que enfrenta actualmente la industria de producción porcina. El riesgo de propagación zoonótica de la gripe, tripanosomiasis, larva migrans, teniasis, sarna, criptosporidiosis, balantidiasis, anquilostomiasis, entamoebiasis y pulgas de los cerdos afectados es real. Debe prestarse atención a las estrategias de control de enfermedades a través de la provisión de recursos y servicios veterinarios, así como producir un cambio de paradigma para la sostenibilidad y la expansión de la capacidad de producción porcina en el país.

Palabras clave: cerdo, producción animal, virosis, enfermedad bacteriana, enfermedad parasitaria, enfermedad gastrointestinal, morbosidad, Nigeria 
